\title{
Prevalence study of overweight/obesity in young adults students and associated factors
}

\author{
Bianca Maria Schneider Pereira Garcia ${ }^{(1)}$, Rosiely Libertino de Menezes ${ }^{(1)}$, Luara Cauper Antony e Souza ${ }^{(1)}$, \\ Wellington Mota Gama ${ }^{(2,3)}$, Danielle Furtado da Silva ${ }^{(2,3)}$, Pedro Vieira da Silva Neto ${ }^{(2,3)}$, Allyson Guimarães da Costa ${ }^{(2,3)}$, \\ Adriana Malheiro Marrie(2,3), Roberta Lins Gonçalves ${ }^{(1)}$, Fernanda Figueroa Sanches ${ }^{(1)}$, Tiótrefis Gomes Fernandes ${ }^{(1)}$, \\ Elisa Brosina de Leon ${ }^{(1,3)}$
}

\begin{abstract}
Introduction: Obesity is determined by energy imbalance between consumed calories and spent calories. The projection is that, in 2025 , about 2.3 billion adults are overweight and over 700 million obese and this is largely associated with an increase in the prevalence of chronic non-communicable diseases. Objectives: The objective of the study was to identify the biological and social-behavioral factors associated with the prevalence of overweight /obesity in a sample of young university students. Method: The study was approved by the Research Ethics Committee of the Federal University of Amazonas. A cross-sectional study was conducted in which were evaluated 174 participants with a mean age of 21 ( \pm 4.3) years, from Federal University of Amazonas, academics of the Physiotherapy and Physical Education Courses. A self-administered questionnaire, that included personal and behavioral data, anthropometric data and blood pressure measurements, was applied. In addition, blood was collected to analyze the lipid profile, glycemia, glycated hemoglobin and insulin and cytokines. The Poisson regression model was used, considering in the final model those variables with $p<0.05$. Results: The study showed that $42 \%(n=73)$ of the evaluated individuals were overweight/obese. The variables significantly associated with overweight/obesity after Poisson analysis were elevated diastolic blood pressure, elevated hip circumference, elevated high neck circumference, and alcohol consumption. Conclusion: It was observed in the study that the behavioral and anthropometric determinants were significantly associated with the increase in the prevalence of overweight/obesity in the sample evaluated. It should be noted that alcohol consumption, from one to five times a week, was significantly associated with the prevalence analyzed.
\end{abstract}

Keywords: Anthropometry; Overweight and obesity; Young Adults.

\section{INTRODUCTION}

Obesity can be defined as a disease characterized by excessive accumulation of body fat, leading to repercussions on health, with significant loss in quality and quantity of life ${ }^{(1)}$. Overweight is a precursor state of obesity, in which the proportion between weight and height of the individual is above the desirable, occurring when the caloric consumption exceeds the energy expenditure ${ }^{(2)}$.

The growing number of overweight and obesity is a major public health problem worldwide, and this is one of the main risk factors for the development of chronic non-communicable diseases (CNCD), such as cardiovascular diseases ${ }^{(3)}$. Latin America, including Brazil, over the last 20 years, has shown a rapid epidemiological and nutritional transition marked by the increase in the prevalence of obesity in the various strata of the population, in the various economic classes, and practically in all age groups ${ }^{(4)}$.
According to the National Health Survey (PNS, 2013) of the Brazilian Institute of Geography and Statistics (IBGE), more than 82 million of people over 18 years old are overweight ${ }^{(5)}$, and according to the World Health Organization (OMS), in 2014 , more than 1.9 billion adults of 18 years of age or older were overweight. Of these, more than 600 million adults were obese. The projection is that, in 2025, about 2.3 billion adults are overweight and over 700 million obese ${ }^{(6)}$. Overweight and obesity are linked to more deaths around the world than underweight. A cross-sectional study conducted at the health campus of the University of Pernambuco with a sample of 240 students with 18 to 22 years observed that obesity and overweight were prevalent in $1.2 \%$ and $9.2 \%$ of the students, respectively ${ }^{(1)}$.

Obesity is the most common form of malnutrition, contributing to the emergence of various comorbidities ${ }^{(6)}$.

Corresponding Author: Name: Elisa Brosina de Leon. Address: Av. General Rodrigo Octávio, 6200, Coroado I. CEP: 69.077-000, Manaus-AM, Brazil.

E-mail: elisadleon@yahoo.com.br. Telephone: +55 (92) 98408-2596.

1. Faculty of Physical Education and Physiotherapy (FEFF) - Federal University of Amazonas (UFAM). Manaus, AM, Brazil.

3. Foundation of Hematology and Hemotherapy of Amazonas (FHEMOAM). Manaus (AM), Brazil.

Full list of author information is available at the end of the article.

Financial support: The authors declare that this study was financed by "Programa Institucional de Bolsas de Iniciação Científica - PIBIC/CNPq".

Submission date 17 September 2016; Acceptance date 3 October 2016; Publication online date 15 December 2016 
Concurrently to the process of its installation, can also occur the development of metabolic abnormalities, such as excessive increase of triglycerides, total cholesterol, low density lipoproteins and glucose ${ }^{(7,8)}$. In this accumulation, both eating and lifestyle habits, sociological factors and metabolic and neuroendocrine changes, as well as hereditary genetic components are involved ${ }^{(9)}$. The risks for these CNCDs increase according to the body mass index (BMI) ${ }^{(6)}$. The National Health and Nutrition Examination Study Survey III (NHANES III), which involved more than 16,000 participants, aimed to provide national health estimates for the population of the United States and found association of obesity with increased prevalence of type 2 diabetes, gallbladder disease, coronary artery disease, systemic arterial hypertension, osteoarthrosis and dyslipidemia ${ }^{(10)}$.

There are still few studies in Brazil that analyze the prevalence of overweight/obesity in the Brazilian population of young university students. In view of the above, this study aimed to identify the association of biological and social-behavioral factors to the prevalence of overweight/obesity in a sample of young Brazilian university students from Manaus, Amazonas.

\section{METHODS}

\section{Study design and population}

This is a cross-sectional study, in which all the students who attended the Federal University of Amazonas in Physical Therapy and Physical Education courses were eligible. People with physical disabilities that made impossible the anthropometric and the pregnant evaluation were excluded. The students were informed of the study and only the participants who agreed and signed the informed consent form were included. Students were interviewed within the university at a previously scheduled time.

The study was carried out in accordance with the instructions contained in Resolution 196/96 of the National Health Council of the Ministry of Health and the Ibero-Latin American Declaration on Ethics and Genetics and approved by the Research Ethics Committee of the Federal University of Amazonas with protocol number 477.327 in a meeting of 20/11/2013.

\section{Evaluation methods}

Participants answered a questionnaire that included personal data, antecedents of family diseases (father, mother and siblings), and behavioral habits such as: use of dietary supplements and previous use of anabolic steroids, smoking, alcohol consumption and frequency of consumption per week, hours of daily sleep, time for leisure activities and physical activity.

For the classification of overweight and obesity, BMI was used, obtained by the ratio weight/ height ${ }^{2}\left(\mathrm{~kg} / \mathrm{m}^{2}\right)$ and defined from the body mass measurement on a properly calibrated anthropometric mechanical scale (Balmak) and stadiometer. The examination was conducted with individuals barefoot, wearing light clothing. The classification of individuals followed the criteria of the National Institutes of Health ${ }^{(11)}$, which classifies the individual as underweight when his BMI is less than $18.5 \mathrm{~kg} / \mathrm{m}^{2}$, appropriate when it is between 18.5 and $24.9 \mathrm{~kg} / \mathrm{m}^{2}$, overweight when it is between 25.0 and $29.9 \mathrm{~kg} / \mathrm{m}^{2}$ and obesity when the $\mathrm{BMI}$ is greater than or equal to $30.0 \mathrm{~kg} / \mathrm{m}^{2}$. In this study, the BMI was considered a dichotomous variable, being considered $\mathrm{BMI}>25.0 \mathrm{~kg} / \mathrm{m}^{2}$ for classification of overweight/obesity.

Abdominal circumference (AC) was measured in centimeters using an inextensible tape measure. The measurement was performed using half the distance between the anterior superior iliac crest and the last rib at the end of expiration. The normal variation of AC was used by the National Cholesterol Education Program ${ }^{(12)}$. For the classification of the participants with altered indexes, the reference values of $<102 \mathrm{~cm}$ to males and $<88 \mathrm{~cm}$ to females ${ }^{(13,14)}$. Hip circumference was obtained placing the tape measure around the hip region in the area with the greatest protuberance. To evaluate the body fat distribution, epidemiological studies have used, since the 70's, the waist-hip ratio (WHR), obtained by dividing the waist and the hip parameters $(\mathrm{cm})$. Among the points of cut established to discriminate adequate values of WHR, the most used has been 0.8 for females and 1.0 for males ${ }^{(15)}$.

The neck circumference (NC) was measured at the base of the neck, at the height of the cricothyroid cartilage. In men with prominence, the circumference of the neck was measured below prominence. As to the classification of the circumference of the neck, were used the values $<39 \mathrm{~cm}$ (normal) and $>39 \mathrm{~cm}$ to males (high) or $<35 \mathrm{~cm}$ (normal) and $>35 \mathrm{~cm}$ (high) to females ${ }^{(14)}$.

Blood pressure (BP) was measured in the right arm after sitting for five minutes. Values were considered altered when systolic BP was above $140 \mathrm{mmHg}$ and/or diastolic above $90 \mathrm{mmHg}$, according to "VI Diretriz Brasileira de Hipertensão Arterial (2010)".

\section{Blood dosages}

After the interviews and the anthropometric and BP measurements, participants were instructed on the fasting (12 hours) for the blood test. Prior to the examination, participants were interviewed to verify the compliance of the fast. The collection was performed in a standardized way and the blood samples were analyzed in a single laboratory. The laboratory tests performed were: lipid profile, glycemia, glycated hemoglobin and insulin. The lipidogram included the determination of total cholesterol, HDL-cholesterol, LDL-cholesterol, VLDL-cholesterol, and triglycerides.

According to the V Diretriz Brasileira de Dislipidemia ${ }^{(16)}$, the reference values of the lipidogram are ideal total cholesterol (TC) $<200 \mathrm{mg} / \mathrm{dL}$; ideal low density lipoprotein colesterol (LDL-C) $<160 \mathrm{mg} / \mathrm{dL}$; very low density lipoprotein colesterol (VLDL-C) 
$<30 \mathrm{mg} / \mathrm{dL}$; ideal high density lipoprotein colesterol (HDL-C) $\geq 40 \mathrm{mg} / \mathrm{dL}$ and ideal triglycerides (TG) $<150 \mathrm{mg} / \mathrm{dL}$. The values of plasma glucose (in $\mathrm{mg} / \mathrm{dL}$ ) considered for diagnosis of diabetes mellitus and its preclinical stages are normal blood glucose $<100 \mathrm{mg} / \mathrm{dL}^{(17)}$. The reference values for glycated hemoglobin considered normal are levels from $4 \%$ to $6 \%{ }^{(18)}$.

The HOMA-IR index, classic indicator of insulin resistance according to $\mathrm{BMI}$, was calculated establishing mean values of $1.2+0.65$ to $\mathrm{BMI}<25 \mathrm{~kg} / \mathrm{m}^{2} ; 1.8+0.98$ to $\mathrm{BMI}$ between 25 to $30 \mathrm{~kg} / \mathrm{m}^{2}$ and $2.9+1.6$ to $\mathrm{BMI}>30 \mathrm{~kg} / \mathrm{m}^{2(19)}$. The dosages of the cytokines were made in the serum, by Citometric Bead Array (CBA), using multiplex kit. Inflammatory cytokines (IL-2, IL-6, TNF- $\alpha$ ), the standard Th2 (IL-4), Th1 (IFN- $\gamma$ ) and suppressor (IL-10) were quantified.

\section{Statistical Analysis}

The categorical variables were used as dichotomous to better fit of the statistical tests. The chi-square test or Fisher's exact test, when necessary, was used for the categorical variables, and the Mann-Whitney test for the continuous variables. For the overweight / obese outcome in comparison with those considered normal, was performed the Poisson regression model with robust variance by the stepwise forward strategy. It was considered as strategy of selection of variables those with $p<0.10$ in bivariate, in the order of the value of $P$, and remained in the final model those variables with $p<0,05$ after adjustment of the others. Statistical significance was considered as $\mathrm{p}<0.05$ and confidence intervals of $95 \%$ (CI 95\%).

\section{RESULTS}

The study obtained a sample of 174 individuals and the prevalence of overweight or obesity found was $42 \%(n=73)$. Mostly of the sample was consisted of women (62.6\%), single (87.7\%), adept to physical activity (81.6\%), non-smokers $(97.7 \%)$, and who reported no use of supplements $(90.2 \%)$ and anabolic (100\%), and the mean age in years was $21 \pm 4.3$. According to the bivariate analysis, those with the highest prevalence of overweight/obesity were: male, smokers, alcohol users, high waist and neck circumference, high systolic and diastolic blood pressure, triglyceride and high VLDL. An association of overweight/obesity was observed for the self-reported diseases: diabetes mellitus and hypercholesterolemia or hypertriglyceridemia and elevated NC. The characteristics of the participants analyzed in the study are described in table 1.

The table 2 shows the mean, standard deviation and value of $p$ of the continuous variables analyzed in the sample, and only hip circumference and insulin presented significant difference between averages.

Table 3 presents the final regression model. It is observed that the variables significantly associated with overweight / obesity in the sample are: elevated diastolic blood pressure (RP=1.11; 1.01-1.23 [IC95\%]); high neck circumference (RP=1.21; 1.01-1.34 [IC95\%]); alcohol consumption ( $R P=1.15$; 1.06-1.25 [IC95\%]), and high hip circumference (RP=1.01; 1.01-1.02 [IC95\%]).

Table 1 - Distribution of prevalence of overweight/obesity for dichotomous variables.

\begin{tabular}{|c|c|c|c|c|}
\hline Variable & $\begin{array}{c}\text { Normal weight } \\
\qquad \mathrm{N}(\%+)\end{array}$ & $\begin{array}{c}\text { Overweight/Obesity } \\
\text { N (\%॰) }\end{array}$ & $\begin{array}{l}\text { Total } \\
\mathbf{N}(\% \ddagger)\end{array}$ & Value of $P$ \\
\hline Total & $101(58.0)$ & $73(42.0)$ & $174(100.0)$ & \\
\hline Gender & & & & 0.01 \\
\hline Female & $71(65.1)$ & $38(34.9)$ & $109(62.6)$ & \\
\hline Male & $30(46.2)$ & $35(53.8)$ & $65(37.4)$ & \\
\hline Marital status & & & & 0.46 \\
\hline Married & $9(50)$ & $9(50)$ & $18(10.3)$ & \\
\hline Single & $92(59)$ & $64(41)$ & $156(89.7)$ & \\
\hline Use of supplements & & & & 0.65 \\
\hline Yes & $9(52.9)$ & $9(47.1)$ & $17(9.8)$ & \\
\hline No & $92(58.6)$ & $65(41.4)$ & $157(90.2)$ & \\
\hline Current use of anabolic & & & & - \\
\hline Yes & - & - & - & \\
\hline No & $101(58)$ & $73(42)$ & $174(100)$ & \\
\hline Pre-use of anabolic & & & & 0.10 \\
\hline Yes & $2(28.6)$ & $5(71.4)$ & $7(4)$ & \\
\hline No & 99 (59.3) & 68 (40.7) & $167(96)$ & \\
\hline
\end{tabular}

† Proportion in line (prevalence). $¥$ Proportion in the column, according to distribution in the sample. RCQ - Waist-hip ratio; BMI - Body Mass Index; SBP-Systolic Blood Pressure; DBP - Diastolic Blood Pressure; LDL- Low density lipoprotein; HDL- High density lipoprotein. 
Table 1 - Continued...

\begin{tabular}{|c|c|c|c|c|}
\hline Variable & $\begin{array}{c}\text { Normal weight } \\
\mathbf{N}\left(\%^{+}\right)\end{array}$ & $\begin{array}{c}\text { Overweight/Obesity } \\
\qquad \mathrm{N}\left(\%^{+}\right)\end{array}$ & $\begin{array}{l}\text { Total } \\
\text { N (\%‡) }\end{array}$ & Value of $P$ \\
\hline Smoke & & & & 0.01 \\
\hline Yes & $0(0)$ & $4(100)$ & $4(2.3)$ & \\
\hline No & $101(59.8)$ & $68(40.2)$ & $169(97.7)$ & \\
\hline Practice of Physical activity & & & & 0.82 \\
\hline$>150 \mathrm{~min} /$ week & $83(58.5)$ & $59(41.5)$ & $142(81.6)$ & \\
\hline$<150 \mathrm{~min} /$ week & $18(56.2)$ & $14(43.8)$ & $32(18.4)$ & \\
\hline Alcohol consumption & & & & 0.06 \\
\hline Yes & $24(42.9)$ & $32(57.1)$ & $56(32.4)$ & \\
\hline No & $76(65)$ & $41(35)$ & $117(67.6)$ & \\
\hline Hours of sleep & & & & 0.29 \\
\hline$>8 \mathrm{hs}$ & $18(66.7)$ & $9(33.3)$ & $27(15.7)$ & \\
\hline$\leq 8 \mathrm{hs}$ & $81(55.9)$ & $64(44.1)$ & $145(84.3)$ & \\
\hline Family hypertension & & & & 0.27 \\
\hline No & $58(56.9)$ & $44(43.1)$ & $102(62.6)$ & \\
\hline Yes & $40(65.6)$ & $21(34.4)$ & $61(37.4)$ & \\
\hline Family Heart Disease & & & & 0.96 \\
\hline No & $91(58.3)$ & 65 (41.7) & $156(90.2)$ & \\
\hline Yes & $10(58.8)$ & $7(41.2)$ & $17(9.8)$ & \\
\hline Family Stroke & & & & 0.23 \\
\hline No & $97(59.1)$ & 67 (40.9) & $164(94.3)$ & \\
\hline Yes & $4(40)$ & $6(60)$ & $10(5.7)$ & \\
\hline Diabetes mellitus familiar & & & & 0.18 \\
\hline No & $84(60)$ & $56(40)$ & $140(82.4)$ & \\
\hline Yes & $14(46.7)$ & $16(53.3)$ & $30(17.6)$ & \\
\hline Family Cholesterol & & & & 0.05 \\
\hline No & $65(64.4)$ & $36(35.6)$ & $101(60.8)$ & \\
\hline Yes & $32(49.2)$ & $33(50.8)$ & $65(39.2)$ & \\
\hline Leisure time & & & & 0.69 \\
\hline No & $25(55.6)$ & $20(44.4)$ & 45 (25.9) & \\
\hline Yes & 76 (58.9) & $53(41.1)$ & $129(74.1)$ & \\
\hline Waist Circumference & & & & 0.001 \\
\hline Appropriate & $101(61.2)$ & $64(38.8)$ & 165 (95.4) & \\
\hline Changed & $0(0)$ & $8(100)$ & $8(4.6)$ & \\
\hline WHR & & & & 0.17 \\
\hline Appropriate & $100(59.2)$ & $69(40.8)$ & 169 (97.7) & \\
\hline Changed & $1(25)$ & $3(75)$ & $4(2.3)$ & \\
\hline Neck Circumference & & & & 0.00 \\
\hline Appropriate & $98(70)$ & $42(30)$ & $140(80.9)$ & \\
\hline Changed & $3(9.1)$ & 30 (90.9) & $33(19.1)$ & \\
\hline SBP & & & & 0.00 \\
\hline Appropriate & $96(63.6)$ & $55(36.4)$ & $151(87.3)$ & \\
\hline Changed & $5(22.7)$ & $17(77.3)$ & $22(12.7)$ & \\
\hline
\end{tabular}

† Proportion in line (prevalence). ₹ Proportion in the column, according to distribution in the sample. RCQ - Waist-hip ratio; BMI - Body Mass Index; SBP-Systolic Blood Pressure; DBP - Diastolic Blood Pressure; LDL- Low density lipoprotein; HDL- High density lipoprotein. 
Table 1 - Continued...

\begin{tabular}{|c|c|c|c|c|}
\hline Variable & $\begin{array}{c}\text { Normal weight } \\
\mathbf{N}(\% \dagger)\end{array}$ & $\begin{array}{c}\text { Overweight/Obesity } \\
\mathbf{N}(\%+)\end{array}$ & $\begin{array}{l}\text { Total } \\
\text { N (\%‡) }\end{array}$ & Value of $P$ \\
\hline DBP & & & & 0.00 \\
\hline Appropriate & $94(67.6)$ & $45(32.4)$ & $139(80.3)$ & \\
\hline Changed & $7(20.6)$ & $27(79.4)$ & 34 (19.7) & \\
\hline Glucose & & & & 0.83 \\
\hline Appropriate & $96(57.5)$ & $71(42.5)$ & $167(98.8)$ & \\
\hline Changed & $1(50)$ & $1(50)$ & $2(1.2)$ & \\
\hline Triglycerides & & & & 0.00 \\
\hline Appropriate & $96(62.3)$ & $58(37.7)$ & $154(90.1)$ & \\
\hline Changed & $3(17.6)$ & $14(82.6)$ & $17(9.9)$ & \\
\hline Cholesterol & & & & 0.22 \\
\hline Appropriate & $92(59.4)$ & $63(40.6)$ & $155(89.6)$ & \\
\hline Changed & $8(44.4)$ & $10(55.6)$ & $18(10.4)$ & \\
\hline HDL & & & & 0.18 \\
\hline Appropriate & 85 (59.9) & $57(40.1)$ & $142(82.6)$ & \\
\hline Changed & $14(46.7)$ & $16(53.3)$ & $30(17.4)$ & \\
\hline LDL & & & & 0.38 \\
\hline Appropriate & $98(58.3)$ & $70(41.7)$ & $168(98.2)$ & \\
\hline Changed & $1(33.3)$ & $2(66.7)$ & $3(1.8)$ & \\
\hline VLDL & & & & 0.00 \\
\hline Appropriate & 97 (62.6) & $58(37.4)$ & $155(90.6)$ & \\
\hline Changed & $2(12.5)$ & $14(87.5)$ & $16(9.4)$ & \\
\hline HOMA-IR & & & & 0.60 \\
\hline Appropriate & $56(57.1)$ & $42(42.9)$ & $98(61.3)$ & \\
\hline Changed & $38(61.3)$ & 24 (38.7) & $62(38.8)$ & \\
\hline
\end{tabular}

† Proportion in line (prevalence). ₹ Proportion in the column, according to distribution in the sample. RCQ-Waist-hip ratio; BMI - Body Mass Index; SBP-Systolic Blood Pressure; DBP - Diastolic Blood Pressure; LDL- Low density lipoprotein; HDL- High density lipoprotein.

\section{DISCUSSION}

Studies that determine the association of biological, psychological and behavioral factors with obesity are important, since it is directly related to a higher morbidity and mortality. In the present study, it was observed that high diastolic blood pressure, elevated hip circumference and high neck circumference were significantly associated with increased prevalence of overweight / obesity in the sample evaluated. Alcohol consumption was also significantly associated with the prevalence analyzed.

The environment has a strong influence on the causes of overweight and obesity, so if family history does not sentence the person to being overweight for the rest of their lives, how they eat and their physical activity habits can do so ${ }^{(6)}$. In our study, we did not observe any association between family history and overweight/obesity. However, we observed an association between alcohol use and overweight/obesity.
There is evidence that abusive consumption of alcohol contributes in a complex way to the increase of BMI among male individuals, favoring the storage of lipids and, consequently, weight gain. This fact was identified in a study on the patterns of alcohol use and its association with obesity, in which it was observed that the moderate drinker presented a $1 \%$ chance of being obese when compared to the abstainers. On the other hand, drinkers who consumed more than four doses a day had a $46 \%$ chance of being obese when compared to non-drinkers ${ }^{(20)}$.

It is important to emphasize that alcohol is also indicated as an appetite stimulant. Studies that verified the food intake performed one hour after alcohol intake confirmed this data ${ }^{(21)}$. Because it has priority in metabolism, alcohol can alter lipid oxidation, contributing to the fat stores, especially in the abdominal region ${ }^{(22)}$.

In our study there was no association of sleep hours with obesity, however several studies indicate that individuals 
Table 2. Distribution of prevalence of overweight/obesity according to continuous variables.

\begin{tabular}{|c|c|c|c|}
\hline Variable & Mean & $\begin{array}{l}\text { Standard } \\
\text { Deviation }\end{array}$ & $\mathbf{P}$ \\
\hline Age (years) & & & 0.24 \\
\hline Appropriate & 21.49 & 4.46 & \\
\hline Overweight/obesity & 22.07 & 4.49 & \\
\hline Hip Circumference (cm) & & & 0.00 \\
\hline Appropriate & 94.42 & 5.86 & \\
\hline Overweight/obesity & 117.45 & 104.91 & \\
\hline Insulin $(\mu \mathrm{UI} / \mathrm{mL})$ & & & 0.00 \\
\hline Appropriate & 45.60 & 194.59 & \\
\hline Overweight/obesity & 91.34 & 273.57 & \\
\hline IL-2 (MIF) & & & 0.65 \\
\hline Appropriate & 283.44 & 182.09 & \\
\hline Overweight/obesity & 247.99 & 91.91 & \\
\hline IL-4 (MIF) & & & 0.95 \\
\hline Appropriate & 230.80 & 206.41 & \\
\hline Overweight/obesity & 184.29 & 98.17 & \\
\hline IL-6 (MIF) & & & 0.71 \\
\hline Appropriate & 318.30 & 323.57 & \\
\hline Overweight/obesity & 381.81 & 734.50 & \\
\hline IL-10 (MIF) & & & 0.66 \\
\hline Appropriate & 188.66 & 205.74 & \\
\hline Overweight/obesity & 150.50 & 102.87 & \\
\hline TNF- $\alpha$ (MIF) & & & 0.09 \\
\hline Appropriate & 227.79 & 226.47 & \\
\hline Overweight/obesity & 175.75 & 154.01 & \\
\hline IFN- $\nu$ (MIF) & & & 0.45 \\
\hline Appropriate & 170.91 & 222.12 & \\
\hline Overweight/obesity & 126.10 & 110.05 & \\
\hline
\end{tabular}

IL-2: Interleukin 2; IL-4: Interleukin 4; IL-6: Interleukin 6; IL-10: Interleukin 10; TNF- $\alpha$ : Tumor necrosis factor alpha; IFN- $\gamma$ : interferon gamma.

Table 3. Final Poisson regression model for overweight / obesity in the sample.

\begin{tabular}{lccc}
\hline \multicolumn{1}{c}{ Variable } & adjusted PR & Cl 95\% & $P$ \\
\hline DBP & & & 0.043 \\
Appropriate & 1 & - & \\
High & 1.11 & $1.01-1.23$ & \\
Hip Circumference * & 1.016 & $1.011-1.021$ & $<0.001$ \\
Neck Circumference & & & $<0.001$ \\
$\quad$ Appropriate & 1 & - & \\
$\quad$ High & 1.21 & $1.01-1.34$ & \\
Alcohol consumption & & & $<0.001$ \\
$\quad$ Yes & 1 & - & \\
No & 1.15 & $1.06-1.25$ & \\
\hline * Continuous variable & & &
\end{tabular}

* Continuous variable who sleep less are more likely to become obese, and that sleep shortening causes an imbalance in endocrine behavior, generating an increase in the appetite and hunger, which may be associated with higher caloric intake and the onset of obesity ${ }^{(23)}$.

The current population spends much less calorie than it has spent in 100 years. The practice of physical activity decreases the risk of atherosclerosis and its consequences besides helping to control obesity, diabetes and dyslipidemias (24). Physical exercise, in its various modalities, promotes calorie burning, muscle toning, improvement of circulation, quality of sleep, reduction of stress and depression, and prevention of hypertension, hypercholesterolemia and diabetes ${ }^{(6)}$. Our study approached a differentiated sample, since they were students of Physical Education and Physiotherapy courses, which are stimulated to the practice of physical activity.

To determine the association between chronic noncommunicable diseases and obesity, anthropometric indicators are used: BMI, AC and WHR ${ }^{(25)}$. In the literature, NC has been used as a simple measure that allows the identification of overweight and obesity and because it is positively correlated with changes in some metabolic syndrome factors ${ }^{(26)}$. The elevated NC leads to an accumulation of fat molecules in the wall of the carotid arteries, favoring the development of cardiovascular diseases (27). Stabe et al., $2013^{(28)}$, demonstrated that NC showed correlation with the $\mathrm{BMI}$ and $\mathrm{AC}$ in both genders and also significant association with the risk factors for metabolic syndrome. Generally, people with a body mass index (BMI) well above normal values have higher blood pressure (BP) values, as well as higher occurrence of arterial hypertension ${ }^{(29)}$.

In the present study, the lack of a probabilistic sampling process and sample calculation in the selection of participants may have led to some selection bias for the purposes of prevalence values, limiting their external validity. However, the analysis methodology used (Poisson with robust variance) for the type of study gave good adjustment.

\section{CONCLUSION}

Obesity is a multifactorial disease and is one of the most important risk factors for other diseases and noncommunicable diseases, such as cardiovascular diseases. The data presented in the present study confirm the influence of biological, psychological and behavioral factors on the prevalence of overweight and obesity. It was observed in the study that the high diastolic blood pressure, elevated hip circumference and high neck circumference variables were significantly associated with overweight/obesity in the sample evaluated. It should be noted that alcohol consumption, from one to five times a week, also showed a significant association with the prevalence analyzed, showing that behavioral habits influenced the observed overweight. 


\section{AUTHOR'S CONTRIBUTION}

BMSPG: Questionnaire collection, anthropometric measurements and preparation of the manuscript; RLM: Questionnaire collection and anthropometric measurements; LCAS: Questionnaire collection and anthropometric measurements; WMG: Questionnaire collection, anthropometric measurements and blood collection; DFS: Questionnaire collection, anthropometric measurements and blood collection; PVSN: blood collection; AGC: Cytokine analysis; RLG: preparation of the manuscript; FFS: preparation of the manuscript; TGF: Statistical analysis and preparation of the manuscript; EBL: Data collection, statistical analysis and preparation of the manuscript.

\section{CONFLICTS OF INTEREST}

The authors declare that they have no conflicts of interest.

\section{AUTHOR DETAILS}

2. Postgraduate in Immunology. Federal University of Amazonas (UFAM). Manaus (AM), Brazil.

\section{REFERENCES}

1. Falcão VTFL, Miranda ML, Silva RMC. Prevalência de obesidade e sobrepeso entre os universitários do campus de saúde da universidade de Pernambuco. Rev. RENE. Fortaleza. set./dez.2007; 8(3): 17-25.

2. Boa Sorte NCA. Problemas de comportamento, resiliência e sobrepeso/ obesidade em adolescentes: estudando um contexto de transição urbanorural. Tese de Doutorado, Salvador 2011.

3. Kenchaiah S, Sesso HD, Gaziano JM. Body mass index and vigorous physical activity and the risk of heart failure among men. Circulation. Jan. 2009; 119(1):44-52.

4. Ferreira TS, Chafauzer C, Araújo Júnior FM, Silva GB. Obesidade central em jovens. Science in Health. 2012; 3(2): 61-73.

5. Instituto Brasileiro de Geografia e Estatística . Pesquisa Nacional de Saúde 2013. Ministério da Saúde, 2015.

6. World Health Organization. Obesity and overweight. Disponível em: http://www.who.int/dietphysicalactivity/publications/facts/obesity/en/. Acesso em: 04 nov.2016.

7. Hill JO. Understanding and addressing the epidemic of obesity: an energy balance perspective. Endocr Reviews. Dec 2006; 27(7):750-61.

8. Lima WA, Glaner MF. Body fat topography as a predictor of an increase in blood lipids. Revista Brasileira Medicina. 2009; 66 (suppl. especial):3-9.

9. Marques-Lopes I, Marti A, Moreno-Aliaga MJ, Martínez A. Aspectos Genéticos da Obesidade. Rev. Nutr. 2004; 17(3):327-338.

10. National Health and Nutrition Examination Study Survey III. Disponível em http://www.cdc.gov/nchs/nhanes/. Acesso em: 04 nov. 2016.

11. National Institutes of Health, National Heart, Lung, and Blood Institute. Clinical guidelines on the identification, evaluation, and treatment of overweight and obesity in adults: the evidence report. Obes Res, 6 suppl. 2:51S-209S, 1998.
12. National Cholesterol Education Program, National Heart, Lung, and Blood Institute; National Institutes of Health. The Practical Guide Identification, Evaluation, and Treatment of Overweight and Obesity in Adults. NIH Publication. September 2002; n(2):5215.

13. Abrantes MM, Lamounier JA, Colosimo EA. Prevalência de sobrepeso e obesidade nas regiões nordeste e sudeste do Brasil. Rev Assoc Med Bras. 2003; 49(2):162-6.

14. Pereira DCR. Análise da circunferência do pescoço como marcador para síndrome metabólica em estudantes de uma Universidade Pública de Fortaleza-CE. Dissertação (Mestrado em Enfermagem), 2012.

15. Machado PAN, Sichieri R. Relação cintura-quadril e fatores de dieta em adultos. Rev Saúde Pública.2002; 36(2):198-204.

16. V Diretriz Brasileiras sobre Dislipidemias e Prevenção da Aterosclerose. Sociedade Brasileira de Cardiologia. Arq. Bras. Cardiol. 2013; 101(4) suppl.1.

17. Wilsgaard T, Arnesen E. Change in serum lipids and body mass index by age, sex, and smoking status: the Tromso study 1986-1995. Ann Epidemiol. 2004;14:265-73.

18. Netto PA, Andriolo A, Filho FF, Tambascia M, Gomes MB, Melo M, et al. J. Bras. Patol. Med. Lab. 2009; 45(1):31-48.

19. Ghiringhello MT, Vieira JG, Tachibana TT, Ferrer C, Maciel RMB, Amioka PHC, et al. Distribution of HOMA-IR in Brazilian Subjects with Different Body Mass Indexes. Arq Bras Endocrin Metab. Jun 2006; 50(3):573-4.

20. Ahmed A, Roher JE. Patterns of alcohol drinking and its association with obesity: data from the third national health and nutrition examination survey, 1988-1994. BMC Public Health. 2005; 5:1-6.

21. Yeomans MR, Caton $S$, Hetherington MM. Alcohol and food intake. Curr Opin Clin Nutr Metab Care. 2003; 6(6): 639-644.

22. Kachani AT, Brasiliano S, Hochgraf PB. O impacto do consumo alcoólico no ganho de peso. Rev. Psiq. Clín. 2008; 35(Supl. 1): 21-24.

23. Gupta NK, Mueller WH, Chan W, Meininger JC. Is obesity associated with poor sleep quality in adolescents? Am J Hum Biol 2002; 14:762-8.

24. Alves JGB, Montenegro FMU, Oliveira FA, Alves RV. Prática de esportes durante a adolescência e atividade física de lazer na vida adulta. Rev Bras Med Esporte. Niterói Sept./Oct. 2005, 11(5):291-294.

25. Pitanga FJG, Lessa I. Indicadores antropométricos de obesidade como instrumento de triagem para risco coronariano elevado em adultos na cidade de Salvador - Bahia. Arq. Bras. Cardiol. 2005; 85(1):26-31.

26. Ben-noun LL, Laor A. Relationship between changes in neck circumference and cardiovascular risk factors. Exp Clin Cardiol. 2006; 11(1):14-20.

27. Preis SR, Massaro JM, Hoffmann U, D'Agostino RB, Levy D, Robins SJ, et al. Neck circumference as a novel measure of cardiometabolic risk: the Framingham Heart Study. J Clin Endocrinol Metab.2010; 95(8):3701-10.

28. Stabe C, Vasques ACJ, Lima MMO, Tambascia MA, Pareja JC, Yamanaka $A$, et al. Neck circumference as a simple tool for identifying the metabolic syndrome and insulin resistance: results from the Brazilian Metabolic Syndrome study (BRAMS). Clin Endocrinol (Oxf). 2013;78(6):874-81, 2013.

29. Cercato C, Mancini MC, Arguello AM, Passos VQ, Villares SM, Halpern A. Systemic hypertension, diabetes mellitus, and dyslipidemia in relation to body mass index: evaluation of a Brazilian population. Rev Hosp Clin 2004;59:113-8. 